\title{
Social Movement in Indonesian Mining Law Enforcement: The case of peasants-scholars nexus in karst mining dispute in Java
}

\author{
Myrna A. Safitri \\ Faculty of Law Pancasila University \\ Jakarta, Indonesia \\ $P h D$ in Law from Leiden University \\ the Netherlands \\ myrnasafitri69@gmail.com
}

\begin{abstract}
Java Island has serious environmental destruction since colonial times. Efforts to reduce the environmental burden of Java have been implemented for centuries by reallocating people and projects to outer islands. Nevertheless, Java is irreplaceable for several reasons. The ability of this island to provide good access to infrastructure and manpower becomes one of its pull factors to several development project, including mining and energy.

One of large-scale mining projects in Java is karst mining in Central Java. Unfortunately, it has led to tremendous legal, social and political issues. The mining of karst in nearby agricultural zone of Kendeng Mountains works at the cost of social conflicts. To access the protection of their land and cultural rights, Javanese peasants have used divers path of justice including access to court. They have obtained support from Indonesian scholars coming from different disciplines. The collaboration of peasants and scholars in judicial process is a new trend in Indonesian legal reform. The case of this mining dispute provides interesting lessons-learned with regard to the issue of social movement in judicial process.

This paper discusses how collective actions of peasants and interdisciplinary scholars work to the enforcement of environmental, mining and administrative law; what factors have influenced the success and failures of these actions and the extent to which has it contributed to judicial activisms that relate to this dispute.
\end{abstract}

Keywords-karst mining, mining dispute, Javanese pea sants, collective action, judicial activism

\section{INT RODUCTION}

In the first quarter of 2016, a nu mber of female peasants from Kendeng, a karst mountains in Central Java Indonesia, held a heroic action to cement their feet in front of the Presidential Palace in Jakarta. The action urged President Joko Widodo to give his attention to the implementation of the Supreme Court's Ruling regarding the annulment of an Environmental Permit (Izin Lingkungan) for a state-owned cement factory named PT. Semen Indonesia. That permit was granted by the Governor of Central Java in 2012 without adequate information and consultation with people in the nearby of that planned mining areas.
Conflict between Kendeng peasants and PT. Semen Indonesia has been going on since 2006. The Govern ment of Indonesia under the administration of Presiden Susilo Bambang Yudhoyono had planned the establishment of cement factory in Java including that that will operate in karst Mountains in the districts of Rembang and Pati in Central Java. Despite facing serious threats with environmental destruction, Java is irreplaceable as the premium industrial location. The ability of this island to provide good access to infrastructure and manpower becomes one of its pull factors to several development project, including karst mining in Kendeng.

From the perspective of socio-legal studies, this conflict is remarkable due to three reasons. Firstly, parties have used different forms of legal arenas to protect their rights and authority. The legal conflict begins with the Governor of Central Java who issued an Environmental Permit or Izin Lingkungan for karst mining to PT. Semen Indonesia in Rembang District in 2012. Objected to this permit, in 2014 several peasants filed an administrative lawsuit that was proceed by the State Admin istrative Court (Pengadilan Tata Usaha Negara) in Semarang, the capital of Central Java, continued in the High Administrative Court (Pengadilan Tinggi Tata Usaha Negara) of Surabaya and finally in the Supreme Court.

The first and appeal courts rejected the claim due to the expiration of lawsuit date[1]. Nevertheless, the Supreme Court accepted the petition of Kendeng people and nullified the Environmental Permit granted by the Governor of Central Java to PT. Semen Indonesia. In this sense, the Court applied a judicial activis $m$ in which environmental justice principles have been central in their decision. Despite the final decision from the Supreme Court, the Governor issued a new Environmental Permit in 2017. This has led to a new conflict with Kendeng people.

Secondly, the Kendeng peasants demonstrate an organized people's movement. The role of women is even central in their struggle. People use various political and cultural strategies to support their actions. Kendeng peas ants 
are part of the Samin community, an indigenous people group in Java. Studies of the Samin show how this community have been promoting strong local wisdom in their agricultural activities for centuries. In the colonial period this community was known to their strong social resistance to colonial tax policy[2]. With strong social resilience, their current movement is formidable.

Lastly, the environmental dispute between the peasants and the cement factory has gained support from many parties such as academics, religious leaders and artists. At least since 2015, there have been various forms of support delivered to Kendeng peasants like of petitions, solidarity actions, academic studies and films.

Previous studies conducted on Kendeng mining dispute are largely focused on social and cultural aspects [3]. Few legal studies have been carried out on this subject, especially those that examine court decisions. More than just examining legal reasoning in court decisions, I consider to see how collective actions of peasants and scholars work to the enforcement of law. In particular, the questions are what factors have influenced the success and failures of these actions and the extent to which has it contributed to judicial activis $m$ in court cases that relate to this dispute?

This paper is divided into three parts. Following this introductory section is an overview of the Samins their mining disputes. Then in part three we focus on the role of scholars to support the struggle of Kendeng peasants. Forms of scholars' involvement for this movement are analyzed. Then part four focuses on judicial activism found in the Supreme Court proceedings. How the scholars' role have been effective for the judicial activis $m$ is analyzed. This paper will be ended with a concluding remark regarding the effectiveness of social movement in judicial activism of mining dispute in Indonesia.

\section{THE SAMINS AND THE MINING DiSPUTE}

The history of the Samins was originated from a Javanese peasants' movement in Dutch colonial times in late $19^{\text {th }}$ century to early $20^{\text {th }}$ century. A man known as Samin Surosentiko led a group of peasants to resist the tax policy of Dutch Colonial government. Promoting a non-violence movement, Samin then developed values of life for his followers.

The social movement of Samins evolved over centuries. They have robust resilience to protect their socio-cultural identity including religion and belief and their traditional agricultural practices. The Saminis $m$ has been the key strength of this movement. The most important Samins' value says that land is not a property. Believing that land is their mother earth, leads the Samins to live in harmony with nature. They have been taught to be survival with their original locale too[2].

The strong value of Saminis $\mathrm{m}$ can be considered as the main reason for people to manage their agricultural land wisely. This makes Kendeng becomes the granary of Java in which paddy fields are well maintained.

The peaceful life in Kendeng started to change when in 2006 PT. Semen Gresik, a state-owned cement factory then merged into a new company named PT. Semen Indonesia, planned to build its factory in karst ecosystem of Kendeng that is situated in the administrative territory of Pati District in Central Java.

Refusing this plan, the Pati peasants filled their claim to the State Admin istrative Court in Semarang. The court accepted this claim by canceling the permit to establish the cement factory. In their consideration, the judges stated that ground water basin in Kendeng Mountains would be threatened if the cement factory was established there. It was stated in the ruling that ground water was an important source of clean water and agriculture [4].

Failed in Pati, PT. Semen Indonesia then transferred its plan to Rembang, a district which is located adjacent to Pati. Conflict occurred when the plan of building cement factory was accommodated by the Rembang District Government in 2010. The Head of District (Bupati) of Rembang issued a decision to allocate a mining exploration area to PT. Semen Indonesia. In accordance with Indonesian Mining Law (Law 4/2009 on Mineral and Coal Mining), the Mining Area (Wilayah Usaha Pertambangan) is the allocated areas that will be granted mining permits (Izin Usaha Pertambangan) either for exploration or production and operation purposes. After the area is established, an exploration mining permit and location permit must be issued before building the cement factory. Prior to this, however, the prospective permit holder must make an Environmental Impact Assessment (Analisis Mengenai Dampak Lingkungan$A M D A L)$ and obtain an environmental permit from local government.

In the case of Rembang, the disputed subject was the Environmental Permit issued in 2012. The peasants felt that they were not getting adequate information. On the contrary, the cement company said it had provided the information through the socialization they did in 2013. But according to the community it did not indicate genuine consultation. The community barely obtained the correct information about the planned construction of this cement factory.

The peasants asked for information regarding the cement factory building to the Central Java Provincial Government. Unfortunately, they did not get the information as expected. The peasants then raised their objection to the planned construction of the cement factory.

Several Kendeng peasants living in Rembang filed a lawsuit with the State Administrative Court in 2014. The court's decision stated that their claim was unacceptable given the time limit for filing a lawsuit. The Indonesian Admin istrative Court Law Number 5 year 1996 states that an administrative lawsuit can be filed within 90 days of receiving or announcing an administrative decree. This decision was then strengthened by High Administrative Court. Decisions in both courts were based solely on evidence that in mid-2013 a meeting were held by local government with the peasants, including those who filed the suit.

People cannot actually accept the two court decisions. However, due to the delay in submitting a cassation application, the decision of the High Admin istrative Court was final. An effort is still possible by filing a petition of review to the Supreme Court. This was used by the peasants to defend for their rights. 
The Supreme Court accepted the peasants' petition and annul the Decree of Central Java Governor regarding the Environmental Permit. Remarkable interpretations had been made by the Supreme Court judges which will be described in section four. Instead of implementing the Supreme Court Ruling, however, the Governor granted a new Environmental Permit. This caused the conflict being escalated until this paper written.

Undoubtedly, the mining administrative dispute filed by the Kendeng peasants has been a noteworthy public interest litigation in Indonesia. The people had been very consistent to use the judicial process to defend for their environ mental justice. In addition to this, the peasants used various other methods. Environmental Justice Atlas, for example, identified at least eight forms of resistance carried out by the peasants. They were artistic and creative actions such as performing guerrilla theatre, blockades, doing public campaigns, marches, occupation of building or public spaces, disseminating discourse of mother nature, women cemented their feet, group prayer and recital of the Koran[5].

Efforts made by these peasants have attracted supports from many parties. Not only NGO activists, proponents are also public figures, religious leaders, film makers, musicians and academics. Here we see that the resistance to injustice which is identical with the history of the Samins has appeared in a broader form. The social movement in the mining dispute in Kendeng cannot be separated from the strong social capital of the Samins. Moreover, the role of middle class groups to support people's access to environmental justice is anotherfascinating phenomenon.

\section{THE ROLE OF SCHOLARS}

As mentioned in section two, scholars are one of the proponents for the Kendeng peasants in their mining dispute. This section describes two kinds of actions carried out by the academics. One is their support to the judicial process and the other can be classified as a political support.

In 2014, academics became expert witnesses in State Admin is trative Court. Four experts shared their knowledge to support the claim of Kendeng people during the judicial proceedings. They were Dr. W. Riawan Tjandra, a legal expert from Atmajaya Catholic University, Dr. Soeryo Adiwibowo, a human ecolog ist from Bogor Agricultural University, a geologist of Bandung Technology Institute Dr. Budi Brahmantyo and Petrasa Wacana, a speleologist.

Their expert testimony was not considered by the judges. The judges were fixated on the formal aspects related to the time for filing an admin istrative lawsuit. In its decision, the judge of the State Administrative Court said that the people's claim was unacceptable because it had exceeded 90 days since the Environmental Permit was received or announced. This consideration referred solely to Article 55 of the Administrative Court Law (Law 5/1986).

The second role performed by the academics was to review the State Admin istrative Court Ruling. The initiator of this study was Dr. Herlambang Perdana, a human rights scholar from the Faculty of Law of Airlangga University. In this review, one of the opinion agreed that the Admin is trative Court Ruling put more formal aspects on the procedures for socializing environmental permit rather than the substantive aspects related to the people's understanding of that permit[6].

When the peasants then submitted their petition for a review of High Court Ruling to the Supreme Court, the academics made an Amicus Curiae brief. Some of the arguments in that Brief related to the interpretation of the lawsuit expiration, the weakness of AMDAL, and the lack of sufficient information on the Environmental[7].

Shortly after the Central Java Governor issued a new Environmental Permit, academics who were members of the Legal Scholars Coalition for Kendeng Justice wrote a legal opinion. As explained in section two, the Governor issued a new environmental permit only a month after the Supreme Court Ruling made. For the scholars, this permit has led to legal uncertainty in the field of administrative law[8].

To respond to the nullification of the Environmental Permit by the Supreme Court, the peasants asked the President to order the Min ister of Environ ment and Forestry make a Strategic Environmental Study (Kajian Lingkungan Hidup Strategis-KLHS). Indonesian Environmental Law requires the Government or regional government to make this study to ensure that the principles of sustainable development are integrated into development policies, programs or plans. KLHS must also be prepared to evaluate policies, programs and development plans that have an impact or pose a risk to the environment. The peasants requested to the Government to provide the KLHS in order to evaluate the establishment of cement factory in Kendeng. The academics became the drafters of the KLHS document[9].

In addition to roles in the field of law, academics' political role is equally important. Two actions can be considered as political support in this regard, namely the petition and the solidarity action of cementing feet.

The petition was first delivered by 258 academics to President Joko Widodo related to their concern on ecological and social crisis in Java. In the petition document, karst mining in Kendeng Mountains has been stated as one of the potential threats to Java ecology. In the second Petition submitted in April 2017, there were demands for the President to cancel the projects of karst mining in Kendeng and to evaluate the establishment of the cement factory[10].

The feet cementing was carried out by several academics in front of the Germany Embassy in Jakarta in May 2018. The aim was to urge that a cement company from Germany, Heidelberg Cement, to end their investment with a cement factory that operates in another part of Kendeng Mountains [11].

The role of scholars in the mining dispute in Kendeng has been proven. Rarely seen that hundreds of Indonesian academics consistently support the peasants in defending for their environmental rights.

\section{THE JUDICIAL ACTIVISM}

This section scrutinizes the Supreme Court's Ruling to see the existence of judicial activis $m$ in the decision and the extent to which it has been influenced by the academics. 
Before we start the discussion, I will first describe the concept of judicial activism and its relation to the rule of law.

\section{A. Judicial Activism and the Rule of Law}

The notion of judicial activis $m$ has been used in various ways and purposes[12]. Mesonis has found three general concepts on judicial activism. The first one refers to the exerc ise of judicial review. In this regard, judges have more liberty to decide constitutional issues and to invalidate legislative or executive actions. The second concept relates to a philosophy of judicial decision-making. Here judges bring their personal views about public policy to guide their decisions and sometimes ignoring precedents. The third concept shows that the Supreme Court and other judges can and should creatively (re)interpret the texts of the law that enable them to fulfil the needs of the society[13].

In relation to this study, judicial activis $m$ can be understood as the act of the judges taking their freedom to do legal interpretation to achieve more substantive social and environmental justice. Judicial activis $m$ in administrative court cases is an important element for the rule of law. Administrative judiciary itself is one of the pillars of the rule of law given its role as a provider of protection for citizens' rights to government actions [14].

Brian Z. Tamanaha explaines that the concept of the rule of law covers the formal and substantive versions which also moves from a thin concept to a thick one[15].

A formal rule of law is marked at the simplest level as a rule-by-law. This refers to the use of law merely as an instrument of legality for government actions. It is not questioned whether the substance of the action refers to justice or not. At a higher level, the rule of law emphasizes formal legality where the law is considered to be general, prospective, clear and certain. At this point, the procedural aspects of law are the key to achieving formal legality. Furthermore, the issue of legality is seen as not sufficient. Legitimate legality arises when legal procedures require the consent of the community.

On the substantive version, the rule of law also moves from the lowest level as a law that protects only individual rights to the law that guarantees the right of broader citizens. Ultimately at the highest level, the substantive rule of law s aims to provide protection for what Tamanaha calls 'social welfare rights'. Here the issue is no longer about the protection of individual rights or the rights of all citizens but further on the goals of social justice including environmental justice.

\section{B. The Judicial Activism in the Supreme Court Ruling on Kendeng Mining Dispute}

The Supreme Court Ruling Number 99/2016 which cancels the Central Java Governor's decree on the Environmental Permit for PT. Semen Indonesia clearly shows the existence of judicial activis $m$. There are three important issues that indicate how that judicial activis $\mathrm{m}$ works.

The first is when the Supreme Court judges interpret the lawsuit expiration. As explained in the previous section, lower level judges stated that the Kendeng peasant's claim was unacceptable because it had exceeded 90 days since the Environmental Permit was announced. This refers to the article regarding the expiration of administrative lawsuit in Law on Admin is trative Court. The meeting held by the local government in mid-2013 was seen by the judges as an evidence that the plaintiff peasants had known about the issuance of the Environmental Permit. Thus, when the lawsuit was filed in 2014, the judges considered this was expired.

The Supreme Court Judge, however, expressed a different opinion. The expiration provisions on administrative disputes in the environmental field according to them are not only based on Administrative Court Law, but also need to consider Environmental Law. Article 89 paragraph (1) of this Law states that the expiration in filing an environmental claim is determined from the existence of pollution and/or environ mental damage. The Supreme Court judges then extended the interpretation of Article 89 paragraph (1) by stating that the expiration of administrative lawsuit for environmental disputes is 90 (ninety) days after the potential risk or loss of the environment found due to the is suance of the Environmental Permit[16].

The second activism can be identified from the opinion of the judges regarding the announcement of environmental permits. The judges said that even though the Environmental Permit had been announced to the public, this could not be justified because the announcement in question did not include any information regarding potential pollution and/or environmental damage due to the Permit. In addition to this, these judges also stated that the formal procedural socialization model was not enough. The judges then said:

"The socialization is not limited to the formalities of its implementation, but must pay attention to the effectiveness or success of the delivery of messages to all groups of people, either directly or indirectly or through representation, and in accordance with the language and level of their [people] social stratification"[16]

It is clear here that the Supreme judges aim to reach the rule of law at the highest level, both in its formal and substantive aspects.

The third judicial activis $m$ relates to the judge's opinion regarding the legal standing of some plaintiffs. The Supreme Court judges argued that the loss due to the permit would not only concern those who stayed in the location where the permit was given, but also in the location around it. Therefore, those who will be affected by it also have a legal standing.

The fourth is related to the opinion regarding the validity of AMDAL documents as a requirement to issue an environmental permits. According to the Supreme judges, the AMDAL document did not explain the restrictions and procedures for mining over areas where groundwater basins were found. This areas is vital for the karst ecosystem and the farming of the people in Kendeng mountains. "It cannot be counted that mining will guarantee the continuity of the aquifer system in this area", said the judges in their decision[16]. 


\section{Scholars and the Judicial Activism}

Looking the judges' interpretations in previous section, it has been proven that the judges consider the opinions of academics who were expert witnesses in Semarang administrative court proceedings.

Riawan Tjandra's interpretation regarding those who have been disadvantaged in environmental disputes, for example, is in line with the judges; argument to accept legal standing from some Kendeng residents who live in villages that are not included in the disputed environmental permit area. According to Tjandra, losses in environmental disputes could be mass. In other words, the impact on the is suance of environmental permits can involve many people around the permitted location.

The reason of Supreme Court judges that the AMDAL was unlawful seemed to be in line with Soeryo Adiwibowo's opinion. In his testimony, Adiwibowo stated that an AMDAL document must considers impact, prediction and evaluation of the planned activities. Reading the AMDAL document, the Supreme Court judges argued that the document could not predict the sustainability of the aquifer system in the existing groundwater basin area if the karst mining conducted. The opinion of geologist Budi Brahmantyo regarding the need for prudential mining in the groundwater basin of Kendeng Mountains has been used by the judges to refuse the AMDAL document.

It cannot be proven in the court decision that the Amicus Brief of the acade mics has influenced to the judges' opinion. Nevertheless, to some points the judges' interpretation regarding the proper socialization of the Environmental Permit (see section three) is apparently in accordance with the Amicus Brief. The Brief states:

The socialization carried out by Rembang District Govern ment to the people affected by the construction of Cement factory in the North of Kendeng Mountains which was only carried out through the website cannot be used as a good socialization effort, especially the condition of the affected people who cannot fully access that website. In addition, the Rembang community has a local tradition of conveying news through the woroworo which is usually done by village functionaries. ... it is an obligation for the local govern ment to carry out a good and massive socialization to the community so that they know the policies taken in relation to the planned establishment of PT. Semen Indonesia[7].

\section{CONCLUSION}

As a public interest litigation, mining dispute in Kendeng confirms the e power of social movements in the enforcement of environmental law in contemporary Indonesia.

This mining dispute also shows the expansion of actors involved in the intended social movement. In many mining cases and other environmental disputes, the movement is mainly supported by NGOs, but in the Kendeng case we can see that academics have play their important roles. Not only in the judicial process but also the political support was also given by this group to Kendeng peasants.
This paper found that the expert witnesses in judicial proceedings and the making of the amicus brief was adequately influence the judicial activism carried out by judges of the Indonesian Supreme Court. Therefore, it is in these two arenas that Indonesian academics actually need to increase their contribution to the achievement of access to environmental justice.

The study then also found that the judicial activism by the Supreme Court judges made the quality of court rulings in mining disputes better. Efforts to improve the rile of law in formal and substantive aspects are very likely if more judicial activism like that occurred in the Kendeng mining dispute is carried out.

\section{ACKNOWLEDGMENT}

Data used in this paper partly based on the author's experience as a member of academics coalition in the advocacy of Kendeng mining dispute. I am grateful to other members of that Coalition who have shared insights to support this movement. This paper is dedicated to all environmental and human rights defenders in Kendeng.

\section{REFERENCES}

[1] Ruling of State Administrative Court in Semarang Number 064/G/2014/PTUN dated 16 April 2015 and Ruling of High Administrative Court in Surabaya Number 135/B/2015/PT.TUN.SBY. 2015.

[2] H. J. Benda and L. Castle, "The Samin moement," Bïdr. tot Taal - , L. - en Volkenkd., vol.125, no. 2,pp.207-240, 1969.

[3] A. Keller and M. Klutte, Dirty cement: The case of Indonesia. 2016.

[4] A. Barahamin, "Kendeng Againtst Cement," 2017. [Online]. Available: $\quad \mathrm{https}: / / \mathrm{mronline}$.org/2017/03/27/kendeng-againstcement/. [Accessed: 21-Aug-2018].

[5] "No Title." [Online]. Available: https://ejatlas.org/conflict/womencement-their-feet-in-protest-again st-cement-factory-indonesia. [Accessed: 24-Aug-2018].

[6] M. A. Safitri, Legal Annotation. 2016.

[7] Amicus Curiae Brief on the Review of State Administrative Court and High Adminsitrative Court rulings. 2016.

[8] "Koalisi Akademisi Hukum Indonesia untuk Keadilan Kendeng," in Opini Hukum, 2017.

[9] Art. 15 para 1 and para 2 of Law $32 / 2009$ on Environmental Protection and Management.

[10] Seruan Moral Aliansi Akademisi UntukKendeng Lestari. 2017.

[11] "No Title." [Online]. Available: http://kbr.id/nasional/052018/yang_disampaikan_petani_kendeng_ke_perwakilan_kedutaan_ jerman/96053.html. [Accessed: 24-Aug-2018].

[12] K. D. Kmiec, "The Origin and Current Meanings of Judicial Activism," Calif. Law Rev., vol.92, no.5, 2004.

[13] G. Mesonis, "Judicial Act ivism in the context of the jurisprudence of the constitutional court." [Online]. Available: http://www.satv.tiesa.gov.lv/en/wpcontent/uploads/sites/2/2017/06/Book_Judicial-activism-of-theConstitutional-Court-in-a-Democratic-State_part_2_ENG.pdf. [Accessed: 21-Aug-2018].

[14] K. M. Stack, "An administrative jurisprudence: The rule of Law in the administrative state. Columbia Law Review 7:115." [Online]. Available: https://columbialawreview.org/content/an-administrativejurisprudence-the-rule-of-law-in-the-administ rative-st ate-2/. [Accessed: 24-Aug-2018].

[15] B. Z. Tamanaha, On the Rule of Law; History, politics, theory. Cambridge: Cambridge University Press.

[16] Supreme Court Ruling. 